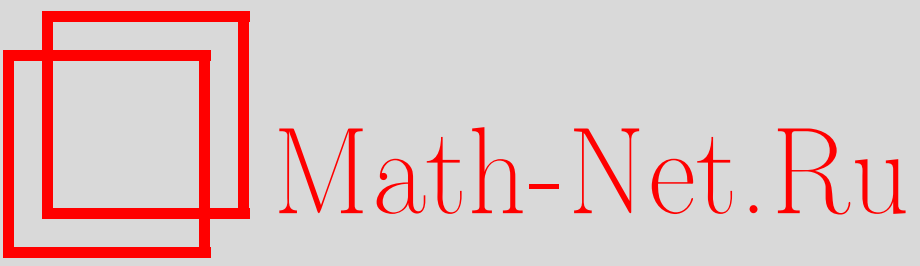

О выдвижении кандидатов на десять премий Европейского математического общества. 4-й Европейский математический конгресс, УМH, 2003, том 58, выпуск 5,207

DOI: https://doi.org/10.4213/rm1637

Использование Общероссийского математического портала Math-Net.Ru подразумевает, что вы прочитали и согласны с пользовательским соглашением

http: //www . mathnet.ru/rus/agreement

Параметры загрузки:

IP : 54.237 .206 .68

26 апреля 2023 г., 14:15:36 


\section{О ВЫДВИЖЕНИИ КАНДИДАТОВ НА ДЕСЯТЬ ПРЕМИЙ ЕВРОПЕЙСКОГО МАТЕМАТИЧЕСКОГО ОБЩЕСТВА. 4-Й ЕВРОПЕЙСКИЙ МАТЕМАТИЧЕСКИЙ КОНГРЕСС}

Основные положения. Всякий европейский математик, которому не исполнится 35 лет к 30 июня 2004 г. и не получавший премии EMO ранее, может быть выдвинут кандидатом на присуждение премии ЕМО на Четвертом европейском математическом конгрессе. Всего будет присуждено 10 премий. Максимально допустимьй возраст может быть превьшен, вплоть до трех лет, если претендент имел соответствующий "перерыв в карьере".

Математики считаются европейскими, если они европейцы по гражданству или их постоянное место работы находится в Европе. Под Европой подразумевается совокупность стран, по крайней мере части которых географически принадлежат к Европе или в которых есть организации члены ЕМО.

Премии будут присуждены за лучшую работу, вьполненную в период до 31 декабря 2003 г.

В своем толковании выражения "лучшая работа" Комитет по присуждению премий может руководствоваться собственными критериями: например, он может сослаться как на качества самой работы, так и на произведенное ею впечатление, ее влияние и т. д.

Выдвижение на премию. Комитет по присуждению премий под руководством проф. Н. Уральцевой (С.-Петербург) отвечает за распространение информации о премиях и выбор победителей. Кандидата может выдвинуть любой, включая членов Комитета по присуждению премий; кандидат также может выдвинуть себя сам. Выдвигающий должен представить в Комитет по присуждению премий всю информацию, относящуюся к делу, в том числе резюме кандидата и необходимые документы. Комитет по присуждению премий должен проинформировать Президента ЕМО о кадидатах не позже, чем за 3 месяца до награждения. Номинация на каждую премию должна сопровождаться письменным обоснованием и отзывом объемом около 100 слов, который мог бы быть зачитан на церемонии награждения. Премии не могут быть поделены между несколькими кандидатами.

Описание награды. Награда включает в себя диплом, содержащий вышеупомянутый отзыв, и денежную премию в размере 5000 евро.

Порядок награждения. О награждениях будет объявлено на Четвертом европейском математическом конгрессе. Лауреатам будет предложено выступить на конгрессе с докладами о своей работе.

Премиальный фонд. Средства для премиального фонда будут собраны организаторами Четвертого европейского математического конгресса.

Сроки выдвижения. Документы на кандидатов должны быть получены в стокголшмском офисе не позже 1 февраля 2004 г.

Почтовьй адрес: 4ECM Organizing Comittee, Prof. Ari Laptev, Department of Mathematics, Royal Institute of Technology, SE-100 44 Stockholm, Sweden

Адреса электронной почты: laptev@math.kth.se, uunur@nur.usr.pu.ru

http://www.math.kth.se/4ecm/

Факс: +46-8-723-17-88

Телефон: +46-8-790-84-86 